\title{
The $125^{\text {th }}$ Anniversary \\ of the Hawaiian Historical Society
}

\author{
SHARI Y. TAMASHIRO
}

This year the Hawaiian Historical Society celebrates its $125^{\text {th }}$ anniversary. Established in 1892 , the HHS is a private not-for-profit organization founded by a group of prominent Hawai'i citizens. Original members included: Charles R. Bishop, President; Joseph S. Emerson, Esq., Vice President; Prof. William D. Alexander, Corresponding Secretary; Rev. Charles M. Hyde, D.D., Recording Secretary; Dr. C. T. Rogers, Librarian; and George P. Castle, Esq., Treasurer. These individuals were dedicated to collecting, preserving, and sharing materials on the history of Hawai'i.

Today, the Society continues its mission by preserving historical materials, presenting public lectures, and publishing scholarly research on the history of Hawai'i. The HHS publishes books in English and Hawaiian, and The Hawaiian Journal of History. The Journal, published annually since 1967 and a benefit of membership, is a leading peer-reviewed journal that focusses on the history of Native Hawaiians and all other cultures in Hawai'i during both pre- and post-contact times.

In recognition of the $125^{\text {th }}$ anniversary, The Hawaiian Journal of History features the Hawaiian Historical Society's logo on its cover. Artist Linda Oszajca designed the logo in 1977 based on elements from an older logo. The two islands represent the Hawaiian Islands, the double-hulled sailing canoe represents the culture of the Native Hawaiians who found and settled the islands, and the three-masted sailing ship represents the cultures of the non-Hawaiians who fol- 
lowed. The President's Report from the Hawaiian Historical Society's 86th Annual Report in 1977 included the following:

Membership. On the subject of membership, Nancy Kwok and Peg Apple have worked hard and effectively to increase the membership rolls. Nancy talked a talented young artist, Linda Oszajca, into designing and producing a new logo for the Society which is decorative and multi-purpose. Linda has adapted her basic design for use on the Newsletter, membership cards and other printed material produced by the Society.

Today, Linda Oszajca is a well-known illustrator, art teacher, graphic and textile designer, author, and fine artist. Her works are found in many public and private places and reflect her love of things Hawaiian.

In addition to featuring its logo on the cover of $H J H 2017$ as part of its $125^{\text {th }}$ anniversary celebration, the Hawaiian Historical Society would also like to recognize the Society's members who have served as its president. They include the following:

$\begin{array}{ll}\text { 1892-1894: } & \text { Charles R. Bishop } \\ \text { 1895-1897: } & \text { William R. Castle } \\ \text { 1898-1904: } & \text { Nathaniel B. Emerson } \\ \text { 1905-1907: } & \text { William D. Alexander } \\ \text { 1908: } & \text { George R. Carter } \\ \text { 1909: } & \text { Alfred S. Hartwell } \\ \text { 1910-1911: } & \text { William D. Westervelt } \\ 1912: & \text { George R. Carter } \\ 1913: & \text { Albert F. Judd } \\ 1914-1915: & \text { George R. Carter } \\ 1916: & \text { Sanford B. Dole } \\ 1917: & \text { Walter F. Frear } \\ 1918: & \text { Sanford B. Dole } \\ 1919-1920: & \text { Joseph S. Emerson } \\ \text { 1921: } & \text { Herbert E. Gregory } \\ \text { 1923-1925: } & \text { Bruce Cartwright } \\ 1926-1933: & \text { Henry B. Restarick } \\ 1934-1935: & \text { Henry P. Judd } \\ 1936: & \text { Ethel M. Damon }\end{array}$




\begin{tabular}{|c|c|}
\hline 1937: & Edwin H. Bryan, Jr. \\
\hline 1938-1939: & Walter F. Frear \\
\hline $1940-1943:$ & Ralph S. Kuykendall \\
\hline 1944: & J. Tice Phillips \\
\hline 1945: & J. Garner Anthony \\
\hline $194^{6:}$ & Samuel Wilder King \\
\hline $1947^{-195^{\circ}}$ & Milton Cades \\
\hline $195^{1-195^{2}}:$ & Nancy Corbett \\
\hline 1953-1955: & Meiric K. Dutton \\
\hline $195^{6-195^{8}:}$ & Charles H. Hunter \\
\hline 1959: & William R. Norwood \\
\hline $1960-1963:$ & Harold W. Kent \\
\hline $1964-1965:$ & Edward Joesting \\
\hline 1966: & Kaupena Wong \\
\hline 1967-1969: & Agnes C. Conrad \\
\hline 1970: & Thomas Nickerson \\
\hline $1971:$ & Donald D. Johnson \\
\hline 1972-1973: & Frances Jackson \\
\hline $1974-1975:$ & E. Alison Kay \\
\hline $1976:$ & Peggy Kai \\
\hline 1977-1978: & Rhoda E. A. Hackler \\
\hline 1979-1980: & Donald D. Johnson \\
\hline 1981-1983: & Alexander Spoehr \\
\hline $1984-1985:$ & Robert L. Cushing \\
\hline $1985-1986:$ & Norman Meller \\
\hline 1986-1988: & C. Dudley Pratt, Jr. \\
\hline 1988-1990: & John T. Goss \\
\hline 1990-1991: & Jim Becker \\
\hline 1991-1993: & C. Dudley Pratt, Jr. \\
\hline 1993-1994: & Thomas K. Lalakea \\
\hline 1994-1996: & Helen G. Chapin \\
\hline 1996-1998: & Mary Philpotts-McGrath \\
\hline 1998-2000: & Thomas S. Dye \\
\hline $2000-2001:$ & John W. McGrath \\
\hline 2001-2004: & Hardy Spoehr \\
\hline 2004-2006: & John Clark \\
\hline 2006-2007: & C. Dudley Pratt,Jr. \\
\hline
\end{tabular}


4 THE HAWAIIAN JOURNAL OF HISTORY

2007-2011: John Clark

2011-2013: Glenn E. Mason

2013-2014: Helen Wong Smith

2014-2015: M. Puakea Nogelmeier

2015-2017: $\quad$ Shari Y. Tamashiro

2017-2018: $\quad$ Ronald C. Williams, Jr. 